\title{
INFORMATION AND PROPAGANDA COMPONENT OF THE RUSSIAN FEDERATION HYBRID AGGRESSION: CONCLUSIONS FOR DEVELOPED DEMOCRATIC COUNTRIES ON THE EXPERIENCE OF UKRAINE
}

\author{
Vadym Torichnyi ${ }^{1}$, Tetiana Biletska ${ }^{1}$, Oleksandr Rybshchun ${ }^{2}$, Dmytro \\ Kupriyenko ${ }^{1}$, Yurii Ivashkov ${ }^{1}$, and Artem Bratko ${ }^{1}$ \\ ${ }^{I}$ National Academy of the State Border Guard Service of Ukraine named after \\ Bohdan Khmelnytskyi and ${ }^{2} I v a n$ Ohiienko Kamianets-Podilskyi National \\ University
}

\begin{abstract}
On the basis of analytical investigations, the current article has carried out an analysis of information and propaganda component of the Russian Federation hybrid aggression against Ukraine at the present historical stage. The key components of Russia's 'information weapon' have been identified, and it has been emphasized that Russia's information and propaganda campaign over the past decades has targeted both the specific states of its aggression and the entire consortium of developed democratic countries in the Western world, especially their major associations - the EU and NATO. The experience of a number of countries, in particular Latvia, Estonia, Georgia, in counteracting Russian propaganda has been investigated.
\end{abstract}

Keywords: hybrid aggression, information security, information confrontation, information and psychological technologies, propaganda, realization of threat scenarios

DOI: https//doi.org/10.3176/tr.2021.3.06

Received 1 July 2021, accepted 6 August 2021, printed and available online 10 September 2021 


\section{Introduction}

Russia's rapid achievement of its political goals on occupying and annexing the Crimean Peninsula in early 2014, virtually without the use of large military contingents, was unexpected for the world. At the same time, mostly non-military tools, such as information-psychological and political technologies, have become essential tools for Russia's success. Russia's approach in Crimea has been particularly impressive, as it has differed significantly from the Russian use of the army in the past on its imperial interests. The Chechen wars (1994-1996, 1999-2009) and the war with Georgia (2008) were criticized internally and externally for excessive use of force and were determined as failed campaigns due to lack of coordination, outdated equipment, and unsuccessful strategies.

After the collapse of the Soviet Union in 1991, the idea that Russian troops were quite outdated dominated for a long time, and that is why Russia's success in Crimea was particularly unexpected for Western democracies. As a result, expert circles expressed the opinion that during the Crimean operation, a 'new art of war' was even used, which, if repeated, could pose a significant threat to developed democracies.

Thus, we believe that conducting of scientific investigations of the RussianUkrainian confrontation can enrich the experience of modern wars and armed conflicts in the interests of their effective settlement.

The purpose of further research analysis of the author's team is to substantiate and prove the hypothesis that Ukraine's systemic unpreparedness to resist Russian propaganda has become one of the dominant preconditions for the beginning of Russian hybrid aggression and its escalation into a 'low-intensity armed conflict'.

Analytical investigations of scientists and publicists were used as a source base of the work, within which the nature and content of Russian propaganda, the specifics of its use in the course of modern military-political conflicts were comprehended. In particular, this is a series of analytical materials of the National Institute for Strategic Studies (basic research institution for analytical and prognosticate support of the President of Ukraine and the National Security and Defence Council of Ukraine); regulations and guidelines governing national and information security in Ukraine (laws, strategies, doctrines, etc.).

The work is constructed as an analytical investigation, which examines information obtained from open sources. The conclusions are preliminary and need further conceptualization.

\section{Main part}

Success in the implementation of Russia's goals for the occupation and annexation of the Crimean Peninsula was served by a number of favorable factors, including:

the predominant pro-Russian civic element, which for many years grew on Russian social traditions and was supported with resources by the Russian government, 
the presence of Russian military facilities and contingents, which, in turn, determined the imperceptible penetration of military invasion forces at the beginning of the armed aggression,

weakening and discrimination of Ukrainian political leadership in the Autonomous Republic of Crimea and in Sevastopol,

the almost complete absence of military resistance and the reaction of the international community, which was stunned and surprised by the speed of Russian action.

It is worth noting that such a convergence of favorable factors will probably be difficult to repeat in most other scenarios. The Russian strategy in Crimea was successful, in our opinion, because the set of military means that the Russians could use and the set of countermeasures that post-revolutionary Ukraine could use allowed the aggressor to achieve specific military-political goals in this case. After all, the importance of the context is crucial in assessing the specific factors that ultimately led to the Russian occupation and annexation of Crimea and the beginning of separatist demonstrations in the Donbas. Misinformation and manipulation of information were used by the aggressor to influence international public opinion, attracting a large irregular contingent.

In the modern world there is an intensive increase of information and communication potential. As a result, there is the formation of a global information society in which information resources become as important as the resources of power and wealth. The current reality is the rapid growth of opportunities for the rapid exchange of political, economic, cultural, scientific and technical, military and other information.

Under such conditions of external misinformation and manipulation of information, full-scale involvement of the state's protective potential for purposeful regulation of information policy becomes historically natural, legitimate and necessary. This is due to national interests aimed at strengthening of information sovereignty, ensuring information security, the integrity of the national information space, its adequate integration into the global information space (Toffler 2004: 672).

Complete or partial refusal of national information sovereignty, neglect in any form of the requirement of strict observance of national interests in the information sphere inevitably lead to loss of control over state sovereignty as a whole. This is a kind of marker that signals the end of the bipolar world and the transition to multivector, the period of the so-called 'hybrid wars', political and economic sanctions, the extreme ideology of the entire system of international relations, cyber terrorism and cybercrime. As the famous American futurist O. Toffler impartially pointed out, at the present stage knowledge and information have become the most important resources of power.

Analysis of the basic concepts of state information policy allows to define the latter as the activity of public authorities and management on the development of a set of measures to identify and meet information needs in society within a single information and cultural and communication space through development, implementation and effective use of modern information products and technologies. 
The part of the information and propaganda component in the wars and armed conflicts of our time is becoming almost equivalent, and in some places even predominant, compared to other forms and methods of modern military-political confrontation. At the same time, it is already well known that the useful properties of information as a means of influence are versatility, easy access, and wide range of applications, permeability and purposefulness. The famous researcher G. Pocheptsov defines 'information wars' as a kind of destabilizing technologies, the essence of which is to "achieve dominance in the symbolic field, because it is the field of interpretation of facts" (Pocheptsov 2001: 256).

An important example of the use of 'information weapons' for analysis was the information campaign used by the Russian Federation against Ukraine during the occupation and annexation of Crimea and the outbreak of war in the Eastern Donbas.

Thus, the director of the National Institute for Strategic Studies, Academician of the National Academy of Sciences of Ukraine V. Horbulin noted that "Russia has used against Ukraine the concept of 'hybrid war', which is largely unique in structural and functional terms: in form it is 'hybrid', and for content - 'asymmetric'. Although each specific element of this 'hybrid war' is not new in essence and has been used in almost all wars of the past, the coherence and relationship of these elements, the dynamism and flexibility of their application, and the growing importance of the information factor are unique. Moreover, the latter, in some cases, becomes an independent component and is no less important than the military". Thus, the novelty and extraordinary dynamism of hybrid confrontation determines the relevance of its further research in the interests of national and international security (Horbulin s.a., Bratko et al. 2021).

This information campaign in Crimea was based on special propaganda - an updated doctrine of information confrontation, which is a synthesis of Soviet (and partly even pre-revolutionary) methods of information warfare and deep elaboration of Western (especially American) information operations at the end of the 20th beginning of the 21st century. Today, the basics of special propaganda are studied jointly with military theory and foreign languages in Russian higher military educational institutions, and it is also included in the training programs for Special Forces, journalists and diplomats.

The doctrine of special propaganda stipulates that the information campaign is a complex of operations in the fields of politics, economics, social dynamics, military actions, intelligence activities, diplomacy, psychological and psycho-terrorist actions, education, information technology and cyber warfare. It deeply incorporates military theory and knowledge of the foundations of the modern social and technological system, defining 'information warfare' as one of the basic instruments of state foreign policy, which strengthens diplomatic leverage to achieve foreign policy goals.

In the specific case of Russian hybrid aggression against Ukraine we have been investigating, the information campaign was aimed primarily at the broad Russianspeaking diasporas (including outside Ukraine) in order to consolidate it around the idea of a civilization struggle between Eurasian culture and the West, while substantiating Russia's application for the status of geopolitical actor. 
One of the conceptual foundations of this information campaign was the work of the Russian right-wing ideologue of the 'Russian world', Alexander Dugin. Based on the provisions on the productivity of new forms of warfare, he emphasizes that the latter are becoming a network phenomenon, and hostilities - a kind of network processes. The researcher proposes the idea of uniting into a single network of military forces in a certain theater of operations, the information apparatus of the state and its cultural resources. All this will have a powerful political and social impact on the enemy. Such a network should include political leaders, diplomats, scientists, military organizations, intelligence, and the media, linking them:

- firstly, the strategic goals of the geopolitical campaign against Western influences,

- secondly, the goals of the military-diplomatic campaign at the local level.

In such a case, the information network must be postmodern (postliberal), one that corresponds to the structures of modern culture and is able to appeal to the masses at the beginning of the 20th century. At the same time, the point is to propagate the ideas of the neoconservative system in the content, where Russia, as a new geopolitical center for the protection of conservative values and traditions, opposes liberalism with its orientations on individualism, technocracy and globalism.

At the action level, Dugin advocates the urgency of establishing total control over social media, where the main driving force should be law-abiding citizens, who are properly organized by the state, are able to disorient, demoralize and block the enemy's ability to defend (Dugin, 1999).

Another well-known ideologue of Russia's 'information warfare' is the political scientist and psychologist Igor Panarin, who proposed centralized management of an information military campaign that would include propaganda, expert analysis, intelligence networks, manipulative media, and directed operations of influence.

These concepts were finally expressed in the updated strategies for the training and use of the Russian armed forces. Thus, a year before the aggression against Ukraine, in January 2013 the report of the Chief of the General Staff of the Armed Forces of the Russian Federation Valerii Gerasimov, "Main trends in the forms and methods of the armed forces", was published, where the author explained that the current conflict differs significantly from world wars of the past and local wars and armed conflicts of the 'cold' civilizational confrontation between the USSR and the Western bloc. Modern conflicts no longer require a strict separation of military and non-military efforts, the concentration of large forces of the warring parties. For the most part, they are not even formally announced. Instead, such confrontations are characterized by non-declaration of war, hybrid operations that combine military and non-military actions and small forces that are aimed at the enemy's critical infrastructure. At the same time, modern warfare, according to Gerasimov, is focused on intelligence and dominance in the information space. It is noteworthy that in the model presented by Gerasimov for the modern Russian war, "The role of non-military methods in resolution of interstate conflicts", the very long information campaign is the basis for forcible implementation of Russia's interests abroad and 
the power resource includes only a reinforcing, auxiliary role in certain stages of the war (Markitantov et al. 2018).

At the same time, another important level of the problem should be noted Russia's information and propaganda resources are not isolated, such diversification allows it to disguise its real goals, and often - to solve a number of tasks as for the near-term perspective and for the long-term perspective by means of a comprehensive advocacy campaign. The complex goal of Russia's information operations is to change the strategic situation in Europe, which will restore its position as a global player along with the modern United States, China and the EU.

Thus, between 2000 and 2010, Russia conducted a series of interconnected campaigns, where propaganda was one of the key resources, on a par with political resources (political will of the top state leadership, legitimized by the institutions of parliament, the Constitutional Court, the Russian Orthodox Church and the media) and force (primarily, military intelligence, which performed operational control over the situation through groups of local combatants). The examples of such were the operations in the Crimea, Donbas, the Baltics, Moldova, Georgia, and Belarus. At a more global, strategic level, Russia's goals are not even the annexation of certain territories of small post-Soviet countries or political and economic pressure on them to achieve certain preferences, but the creation and use of rifts among Western bloc countries, NATO delegitimization and EU weakening.

Returning directly to information and propaganda component, as correctly identified by Andrew Wilson (Professor of Ukrainian Studies, School of Slavic and Eastern European Studies, University College of London), it performs four interrelated tasks:

- distracts and disorients the Western audience,

- strengthens the already formed public opinion,

- mobilizes a pro-Russian audience,

- forms an 'alternative reality'.

At the same time, the tools for the implementation of the above-mentioned tasks are Russian state and pro-Russian non-state media, 'troll factories', puppet civic associations (especially important in areas of protracted conflicts, such as Transnistria, Crimea, Donbass, Abkhazia, North Ossetia, Nagorno-Karabakh, Northern Caucasus, Northern Cyprus, Syria), Russian Orthodox Church.

Additional instruments are the financial resources through which political and party groups are supported abroad, especially in Europe, not only pro-Russian, but also in general capable of destabilizing the existing political systems. For example, Hungarian "Jobbik Magyarországért Mozgalom", "Fidesz - Magyar Polgári Szövetség", British "United Kingdom Independence Party, UKIP", "British National Party, BNP", Greek " $\Lambda \alpha$ "Alternative für Deutschland, AfD", "Patriotische Europäer gegen die Islamisierung des Abendlandes", Bulgarian "Ataka", French "Rassemblement national", fraction "Europe of Nations and Freedom" in the European Parliament. At the heart of the discourses conducted through propaganda channels are politicized history, issues of national strife, linguistic and religious affiliation, the cultivation of symbolic 
statuses of the historical heritage of the Russian and Soviet past, and so on (Herd and Marshall 2016).

At a time when the doctrine of modern warfare was being formed in Russia, in Ukraine the main emphasis of information policy was focused on strategies for building a new civil society and Ukraine's integration into the European community, which, unfortunately, did not allow timely and effective counteract to aggression in 2014.

Thus, analyzing the content of analytical materials of the Institute for Strategic Studies in the section Information Policy for 2010-2013 (Institute of Strategic Research s.a.), we note that their main topics were: the development of e-democracy, information policy on European integration, information technologies as a factor of social transformations, countering cybercrime and others.

It should be noted that the "Strategy for Cyber Security of Ukraine" before the war was only in the draft (Strategy of ensuring ... Ukraine s.a.), respectively, in fact, there was no readiness to use the Armed Forces of Ukraine in a "cyber war". There were also insufficient opportunities to repel armed aggression, taking into account new challenges and threats in the information sphere. Also there were insufficient protection of information infrastructure (including military and dual-use) from real and potential cyber threats. In fact, there was no system for training specialists in the field of cybersecurity for the needs of the Armed Forces of Ukraine and other components of the security and defense sector of Ukraine.

The Doctrine of Information Security of Ukraine from 2009 (Decree of the President of Ukraine) was also inconsistent with the requirements of the time, in which the probability of waging an information war against Ukraine was underestimated and there was no requirement to train appropriate forces and means for counteraction and defense in the information sphere.

The consequences of all the processes outlined above were that with the start of the Russian aggression in 2014, Ukraine was unable to fully counteract, primarily in the information sphere. Thus, already during the annexation of the Crimean Peninsula, the Russians conducted a powerful information and psychological campaign, the tasks of which were demoralization and formation at the level of mass consciousness of 'treasonous sentiments', recruitment of formal and informal leaders, presentation of distorted media vision of events, moral and psychological support of the population with pro-Russian sentiments and modelling of a common 'happy future'. The target audiences constituted the staff of the legislative, executive and judicial authorities of the Autonomous Republic of Crimea, including the personnel of the Armed Forces and law enforcement agencies of Ukraine, as well as pro-Russian and loyal to the Russian authorities of the Crimean population.

At the same time, a wide range of information channels (traditional and electronic media, Internet media, social networks) and methods of information and psychological struggle were used. As noted in the analytical report "On the information and psychological component of the Russian Federation's aggression against Ukraine (as a result of the events of March 1-2, 2014)" (On information and psychological ...), opposition from Ukraine was extremely weak: inactive official 
websites of key state institutions, insufficient activity of major media resources (for example, on the problematic days of March 1-2, 2014, a significant part of domestic TV channels did not change the broadcasting network, limiting themselves to the bilingual banner "United Ukraine! / United Country!"). One of the few effective forms of resistance was the rapid reaction of public activists, but it was clearly insufficient to fully counter the aggressor.

The situation was also exacerbated by the fact that in Ukraine as a whole, since its independence, the issue of building an information security system at the legislative level has hardly been raised. As a result, having undergone active information and propaganda aggression, the newly formed 'revolutionary' political regime proved to be practically incapable in this area. State functions of information security were scattered among a number of 'competing' ministries and agencies, which in certain respects duplicated functions. At the same time, general coordination and monitoring of the information security system was insufficient. As a result of these processes, as we noted above, the first decisions at the time of the annexation of Crimea and the demoralization of the population of Eastern Donbas were extremely primitive, for example, to limit Russian television broadcasting.

Thus, in March 2014, 5 Russian TV channels were banned in Ukraine, and by December 2015, 25 were already banned.

Subsequently, a series of restrictive measures were introduced on the share of Russian-language products on Ukrainian TV channels, and since March 2015, a list of Russian propaganda films has been a taboo at the legislative level.

The realization that a new aggression had been launched against Ukraine, which would later be described as a 'hybrid war', led to the development of the foundations for a new security and defense system, in which the issue of information security was important.

Thus, in the spring of 2014, threats and challenges in the information and psychological sphere were classified as threats to Ukraine's national security (On separate directions ...). An active study of attempts to counter foreign information aggression begins (Evolution of foreign language ...). Propaganda is reinterpreted as a tool of information special operations. Attempts are being made to develop effective counter-propaganda mechanisms (Propaganda spread ...).

From the middle of 2014, the systematic institutionalization of the information security system begins. Moreover, one of the problems here was the attempt to prevent actions that could be further considered as a violation of freedom of speech in Ukraine as one of the fundamental foundations of modern liberal democracy.

Thus, in December 2014, the Ministry of Information Policy was created, the Concept of Information Security of Ukraine was developed, a number of patriotic information campaigns were launched, in particular, Crimea is Ukraine, Protecting Ukraine and others.

In October 2015, a separate law required domestic broadcasters to provide public information about their owners and sponsors.

However, the real effectiveness of all these measures, as shown by public opinion polls at the time, was extremely weak. Thus, according to polls conducted by the 
Kyiv International Institute of Sociology, $42 \%$ of the population of southern Ukraine were convinced that the events on the Maidan were a violent seizure of power; $28 \%$ - that there is a civil war in eastern Ukraine (Shutov 2016).

Since 2016, the Ukrainian authorities face a new problem - the reintegration of the population of the occupied and liberated territories into the domestic cultural and information environment (Plain language).

In recent years, when the armed conflict in eastern Ukraine has become a positional with low intensity, the issue of information confrontation is gradually transformed into ensuring stability to destructive information and psychological influences, for example, through the exchange of experience in public-private partnership in cybersecurity, implementation of media literacy for certain target groups, etc. However, at the fundamental level the problem is not resolved, as neither at the institutional nor at the regulatory (doctrinal) level a fully effective system of information security in a hybrid aggression of the enemy in Ukraine has yet been developed.

Based on the results of further analysis of events in Estonia (2007), Georgia (2008) and Ukraine, we summarize that:

- the main method of Russian propaganda in a conflict situation is misinformation. At the same time, the objects of aggression are dispraised in order to discredit them in the eyes of both Russian and foreign audiences,

- information and propaganda channels include the full range of media: Russian state TV channels, pro-Russian media in the country of aggression, online media, web resources (e.g., LiveJournal, Liveinternet), large-scale Internet trolling in social networks, information channels of separatist associations, even networks of mobile operators.

Russia spends enormous financial resources on information and propaganda support, incommensurable with the capabilities of small post-Soviet countries.

Thus, these difficulties, which Ukraine faced as a result of six years of resistance to Russian hybrid aggression, are aimed at finding models for effective counteraction to Russian propaganda in other countries. Such were formed especially in the Baltics.

In 2007, in response to the dismantling of a monument to Soviet soldiers, Russia used a combined attack on Estonia, combining information and propaganda influence, diplomatic and trade and economic pressure, the potential of local political groups, and massive cyberattacks.

In view of this, Estonia has chosen the way aimed at:

- increase of funding to create balanced sources of information that, by producing 'positive messages', would be able to counteract the Russian and pro-Russian media,

- creation of EastStratCom Team - a permanent information unit of the EU,

- support for press freedom in the Eastern Partnership countries,

- ensuring the availability of their information materials for Russianspeaking audiences (Weibel 2016). 
Another Baltic country - Latvia, with a large ethnic Russian and Russian-speaking population (up to $26 \%$ of the population), actively uses the support of the NATO Centre for advanced experience in Strategic Communications in Riga to counter the narratives of the pro-Russian media (primarily RT informational agency). It is noteworthy that in the EU there is a similar resource - the Task Force on Strategic Communications, assigned with tasks of the coverage and debunking of Russian propaganda.

Measures recommended for European countries, in the domestic political life of which the 'Russian trace' is periodically monitored, can also be useful for Ukraine (Smolenova 2016):

- monitor the impact of Russian propaganda on public opinion,

- to deconstruct and publish the facts of Russian information and propaganda actions,

- to increase the level of information competence of its citizens,

- to refute and explain the main propaganda theses.

- to institutionalize more actively 'information security'.

It should be noted here again that in general, the information and propaganda campaign conducted by Russia in recent decades is aimed, besides direct objects, also against the entire consortium of leading Western countries and their main associations - the EU and NATO. At the same time, the discourse of propaganda is often intertwined with strange chimeras, when, for example, Donbas separatism is presented almost historically due to the separatism of the Spanish Basques or Ulster Irish, the protection of the Russian-speaking population is consistent with the protection of rights and freedoms in Western Europe. At the same time, such a discourse is reinforced by targeted information attacks: on the problems caused by migration in Germany, Brexit processes, mistakes in the election race in the United States, and so on.

Of course, today, considerable Western experience has been gained in countering Russian propaganda and disinformation. In particular, the following can be extremely useful for Ukraine: "Common principles for combating hybrid threats the response of the European Union" (Joint Framework) - a harmonizing act of EU member states on combating hybrid threats, in particular, of an informational nature; European Parliament resolution "Strategic Communications of the European Union as a countermeasure to third party propaganda" (European Parliament resolution ...), based on the Action Plan on Strategic Communication and which presents the main aspects of information and propaganda activity of the Russian Federation.

It is equally important to maintain close ties with the EU's Task Force on Strategic Communications (East Strat Com Task Force), the EU's foreign policy service, whose main tasks include counteracting misinformation and providing information support to a number of post-Soviet countries, including Ukraine. At the same time, it is important to note that the information and analytical resource of the department - uvsdisinfo.eu is quite an effective tool of counter-propaganda, which can be considered (News and analytics ..., Buinauskas et al. 2016) as domestic analogues and others. 


\section{Conclusion}

In general, according to the results of the analysis, we can consider the following conclusions being confirmed:

- firstly, in preparing and carrying out an act of military-political aggression against Ukraine, the Russian Federation applied a modernized strategic approach, in which the information and propaganda component had one of the dominant positions,

- secondly, at the beginning of the hybrid aggression against state sovereignty and territorial integrity, Ukraine was not ready for a massive information and propaganda attack as part of a new generation of military conflict,

- thirdly, the countermeasures applied by Ukraine in the information sphere proved to be insufficient due to the lack of such experience, trained personnel and adequate resources, obsolete information infrastructure and unsystematic actions in ensuring information security,

- fourthly, under the conditions that the main feature of Russia's militarypolitical campaign against Ukraine was its information and propaganda component, Ukraine's systemic unwillingness to resist propaganda became one of the main preconditions for the beginning of Russian aggression and evolution to a 'low-intensity armed conflict'.

At the same time, developed democracies who have experience in countering Russian propaganda have accumulated a proven arsenal of effective forms and organizational and technical measures that can be used in the interests of building a national system of information security. At the same time, the implementation of this experience should take into account two important caveats:

1. borrowing of experience should not become a 'blind' copying, because it should take into account the cultural, historical, institutional and other realities of the current situation in Ukraine,

2. Russian propaganda is rapidly evolving in its forms and technologies, has significant resources that are directed to it, which is why it requires regular monitoring and audit of the effectiveness of counter-propaganda scenarios of developed democracies.

Thus, the hypothesis formulated at the beginning of the study was confirmed, the purpose of the article was achieved. 
Addresses:

Vadym Torichnyi

Faculty of the Managerial Personnel Training

National Academy of the State Border Guard Service of Ukraine

named after Bohdan Khmelnytskyi

Khmelnytskyi, 29007, Ukraine

E-mail: theotorik@gmail.com

Tetiana Biletska

Faculty of the Operative and Service Activity Ensuring

National Academy of the State Border Guard Service of Ukraine

named after Bohdan Khmelnytskyi

Khmelnytskyi,29007, Ukraine.

E-mail: bitavi_21@ukr.net

Oleksandr Rybshchun

Historical Faculty

Ivan Ohiienko Kamianets-Podilskyi National University

Kamianets-Podilskyi, Ukraine

E-mail: arubshchun@gmail.com

Dmytro Kupriyenko

Faculty of the Managerial Personnel Training

National Academy of the State Border Guard Service of Ukraine

named after Bohdan Khmelnytskyi

Khmelnytskyi, 29007, Ukraine

E-mail: dakupriyenko@gmail.com

Yurii Ivashkov

Faculty of the operative and service activity ensuring

National Academy of the State Border Guard Service of Ukraine

named after Bohdan Khmelnytskyi

Khmelnytskyi, 29007, Ukraine

E-mail: yuriy-ivashkov@ukr.net

Artem Bratko

Faculty of the State Border Security and Protection

National Academy of the State Border Guard Service of Ukraine

named after Bohdan Khmelnytskyi

Khmelnytskyi, 29007, Ukraine

E-mail: bratkoav84@gmail.com 


\section{References}

Bratko, A., D. Zaharchuk, and V. Zolka (2021) "Hybrid warfare - a threat to the national security of the state". Revista de Estudios en Seguridad Internacional 7, 1, 147-160. Doi: http://dx.doi. org $/ 10.18847 / 1.13 .10$

Buinauskas D., V. Keršanskas, and L. Kasčiūnas (2016) "A propaganda research model for the analysis of Russian propaganda in Lithuania”. Politologija 83, 3, 3-40. Doi: https://doi.org/10.15388/ Polit.2016.3.10236

Decree of the President of Ukraine (s.a.) On Doctrine of information security of Ukraine. Available online at $<$ https://zakon.rada.gov.ua/laws/show/514/2009\#Text $>$. Accessed on 01.07.2021.

Dugin A. (1999) Bases of geo-politics: geo-political future of Russia. Moscow: Arktogeya,

European Parliament resolution of 23 November 2016 on EU strategic communication to counteract propaganda against it by third parties. Available online at <http://www. https://www.europarl. europa.eu/doceo/document/TA-8-2016-0441_EN.html?redirect>. Accessed on 01.07.2021.

Evolution of foreign language in foreign countries: experience for Ukraine. Analytical note. Available online at $<$ https://niss.gov.ua/doslidzhennya/informaciyni-strategii/evolyuciya-inomovlennyav-inozemnikh-derzhavakh-dosvid-dlya>. Accessed on 01.07.2021.

Herd, Graeme P. and George C. Marshall (2016) "Russian information operations seek strategic realignment in Europe". per Concordiam 7, 7-13.

Horbulin, V. (s.a.) 'Hybrid war' as a key instrument of Russian geo strategy of revenge: mirror of a week. Available online at $<$ https://dt.ua/internal/gibridna-viyna-yak-klyuchoviy-instrumentrosiyskoyi-geostrategiyi-revanshu-html $>$. Accessed on 01.07.2021.

Institute of strategic research (s.a.) Information policy. Available online at $<$ https://niss.gov.ua/ doslidzhennya/informaciyna-politika>. Accessed on 01.07.2021.9.

Joint Framework on countering hybrid threats a European Union response. Available online at $<\mathrm{http} / /$ bit.ly/2t0ywSh>. Accessed on 01.07.2021.

Markitantov V., O. Rybshchun, and Yu. Stoliar (2018) Russian hybrid war: from doctrine to tactics: manual. Kamianets-Podilskyi: Publishing office Ruta.

News and analytics of Ukraine. Available online at $<$ https://www.digestagency.com/>. Accessed on 01.07.2021.

On information and psychological component of the Russian Federation aggression against Ukraine (on the results of events from 1-2 March 2014). Analytical note. Available online at $<\mathrm{https}$ :/ niss.gov.ua/doslidzhennya/informaciyni-strategii/schodo-informaciyno-psikhologichnoiskladovoi-agresii $>$. Accessed on 01.07.2021.

On separate directions of improvement of the state information policy of Ukraine. Analytical note. Available online at <https://niss.gov.ua/doslidzhennya/informaciyni-strategii/schodookremikh-napryamiv-vdoskonalennya-derzhavnoi>. Accessed on 01.07.2021.

Plain language / Plain language in provision of communicative connection authority - the public at the occupied and released territories. Available online at $<$ https://niss.gov.ua/doslidzhennya/ informaciyna-politika?page $=2>$. Accessed on 01.07.2021.

Pocheptsov, H. (2001) Information \& disinformation. Kiev: Nika-Center.

Propaganda spread to occurring national and international hostility: problems of determination and counteraction. Analytical note. Available online at $<$ https://niss.gov.ua/doslidzhennya/ informaciyni-strategii/propaganda-spryamovana-na-rozpalyuvannya-nacionalnoi-ta>. Accessed on 01.07.2021. 
Shutov, R. (2016) "Russian propaganda in Ukraine" per Concordiam 7, 37-38.

Smolenova, I. (2016) Campaign on pro-Russian disinformation in the Czech Republic and Slovakia, per Concordiam, 7, 2016, p. 26-29.

Strategy of ensuring of cyber security of Ukraine (s.a.) Available online at $<$ https://niss.gov.ua/sites/ default/files/2013-11/kiberstrateg.pdf $>$. Accessed on 01.07.2021.

Toffler, E. (2004) Metamorphosis of power / power shift: knowledge, wealth and violence at the edge of the 21 st century. AST.

Weibel, V. (2016) "Russia manipulates mass media as a tool of psychological war". per Concordiam 7, 14-19. 